\title{
DNA microarray-based detection of Coxiella burnetii, the causative agent of $\mathrm{Q}$ fever
}

\author{
Gernot Schmoock ${ }^{1}$, Ralf Ehricht ${ }^{2}$ and Lisa D Sprague ${ }^{1 *}$
}

\begin{abstract}
Background: An easy-to-handle microarray assay based on the cost-effective ArrayTube ${ }^{\mathrm{TM}}$ platform has been designed for the rapid and unequivocal identification of Coxiella burnetii, the causative agent of $\mathrm{Q}$ fever. The gene targets include the chromosomally coded markers icd, omp/com1, and IS1111 as well as the plasmid coded markers cbbE and cbhE.

Results: A representative panel comprising 50 German C. burnetii isolates and 10 clinical samples was examined to validate the test. All tested isolates harboured plasmid QpH1 and were correctly identified, corresponding to 100\% sensitivity. The assay's limit of detection was 100 genome equivalents (GE) for icd, omp/com1, cbbE and cbhE and 10 GE for IS1111. Assay specificity was 100\% as determined by analysing a panel of 37 non-Coxiella strains.

Conclusions: The present array is a rational assembly of established and evaluated targets for the rapid and unequivocal detection of $C$. burnetii. This array could be applied to the screening of vaginal swabs from small ruminants; screening of environmental samples e.g. on farms or screening of human samples.
\end{abstract}

Keywords: Coxiella burnetii, Q fever, Oligonucleotide microarray, Hybridisation, PCR, Zoonosis

\section{Background}

The causative agent of the zoonosis Q fever, Coxiella burnetii is listed by the United States Centers for Disease Control and Prevention (CDC) as a Category B pathogen and potential bioterrorism agent [1]. This small, Gramnegative, nonmotile, obligate intracellular bacterium is highly infectious and experimental data suggest that less than 10 organisms can cause infection. In animals, infection takes mostly a subclinical or inapparent course but abortions or birth of weak offspring, especially in small ruminants, can occur $[2,3]$. In humans, the clinical picture can range from asymptomatic to severe, usually presenting with fever, severe headache, myalgia and fatigue, frequently accompanied by atypical pneumonia and/or hepatitis. Chronic Q fever, i.e. persistence of infection exceeding a period of six months duration, may lead to endocarditis, which can be fatal. Additionally, chronic hepatitis, osteomyelitis, and septic arthritis are known sequelae [4].

\footnotetext{
* Correspondence: lisa.sprague@fli.bund.de

'Friedrich-Loeffler-Institut, Institut für Bakterielle Infektionen und Zoonosen, Naumburger Str. 96a, Jena 07743, Germany

Full list of author information is available at the end of the article
}

Clinical diagnosis of $C$. burnetii infections in man and animal usually relies on serology, despite molecular methods such as PCR-based assays being more suitable in terms of speed and specificity, especially within the first couple of weeks after onset of disease [5-7]. However, although PCR assays are generally very fast and sensitive, their multiplexing capacity is limited. Moreover, due to their high specificity, they are incapable of detecting e.g. novel species or variants of a known species [8]. Microarrays on the other hand can be designed with a multitude of different probes either suitable for species identification by using highly specific probes, or for the detection of related or novel species by using probes lying within conserved regions [8]. A further benefit of the multiple targets on an array is that they can partly mitigate the weakness of diagnostic PCR assays when the PCR primer target contains point mutations. These mutations can be present in variants within a species and can lead to false negative results.

In this study, we describe a microarray-based method adapted to the ArrayTube ${ }^{\mathrm{mi}}$ (AT) platform, using three chromosomal (icd, omp/com1, and IS1111) and two plasmid $(c b b E, c b h E)$ coded targets for the detection of C. burnetii. This platform has repeatedly been shown to 
be suitable for detecting other biological agents such as Burkholderia mallei/pseudomallei, Brucella spp., Bacillus anthracis, and Chlamydia spp. [9-12], for bacterial species differentiation and genotyping [13] and for automation-based applications.

\section{Methods}

\section{Cell culture and bacterial isolates}

The heat inactivated preparations of C. burnetii isolates and clinical samples used in this study were obtained from the National Reference Laboratory of Q Fever at the Federal Research Institute for Animal Health (Friedrich-LoefflerInstitut (FLI), Jena, Germany) [14] (Table 1).
All non-Coxiella bacteria used in this study were obtained from the German Collection of Microorganisms and Cultures (DSMZ, Braunschweig, Germany), and from the strain collection of the Institute of Bacterial Infections and Zoonoses at the Federal Research Institute for Animal Health (FLI, Jena, Germany). Bacteria were grown on standard media under conditions recommended by the respective bacterial strain collections. DNA from Bartonella spp, Chlamydia spp, Francisella spp, Salmonella typhimurium, Haemophilus influenzae, and Legionella pneumophila was obtained from the Institute for Medical Microbiology and Infection Control, Goethe University, Frankfurt/M., from the National Reference Laboratory of Psittacosis, from the National Reference Laboratory of

Table 1 Panel of tested Coxiella isolates and clinical samples isolated in Germany

\begin{tabular}{|c|c|c|c|c|c|c|c|}
\hline Year & Identifier & Host & Sample & Year & Identifier & Host & Sample \\
\hline 1997 & DP677 & fallow deer & isolate & 2009 & DP758 & goat & isolate \\
\hline 1997 & DP684 & cattle & isolate & 2009 & DP792 & sheep & isolate \\
\hline 1997 & DP822 & goat & isolate & 2009 & DP795 & sheep & isolate \\
\hline 1998 & DP682 & goat & isolate & 2009 & DP798 & sheep & isolate \\
\hline 1998 & DP685 & tick & isolate & 2009 & DP801 & sheep & isolate \\
\hline 1998 & DP751 & sheep & isolate & 2009 & DP804 & sheep & isolate \\
\hline 1998 & DP752 & sheep & isolate & 2009 & DP807 & sheep & isolate \\
\hline 1998 & DP759 & tick & isolate & 2009 & DP810 & sheep & isolate \\
\hline 1999 & DP683 & sheep & isolate & 2009 & DP813 & sheep & isolate \\
\hline 1999 & DP730 & cattle & isolate & 2010 & 12Q1649 & cattle & isolate \\
\hline 2001 & DP678 & sheep & isolate & 2011 & 12Q1650 & sheep & isolate \\
\hline 2001 & DP748 & cattle & isolate & 2011 & 12Q1651 & sheep & isolate \\
\hline 2001 & DP753 & sheep & isolate & 2011 & 12Q1652 & sheep & isolate \\
\hline 2002 & DP734 & cattle & isolate & 2011 & 12Q1653 & sheep & isolate \\
\hline 2002 & DP791 & sheep & isolate & 2011 & 12Q1654 & sheep & isolate \\
\hline 2003 & DP676 & human & isolate & 2011 & 12Q1655 & sheep & isolate \\
\hline 2003 & DP679 & cattle & isolate & 2011 & 12Q1656 & sheep & isolate \\
\hline 2003 & DP680 & sheep & isolate & 2012 & 12Q1657 & cattle & isolate \\
\hline 2003 & DP749 & cattle & isolate & 2012 & 12Q1658 & cattle & isolate \\
\hline 2003 & DP754 & sheep & isolate & & & & \\
\hline 2004 & DP681 & goat & isolate & & & & \\
\hline 2004 & DP731 & sheep & isolate & 2008 & $15 / 24$ & sheep & vaginal swab \\
\hline 2004 & DP732 & sheep & isolate & 2009 & $34 / 19$ & sheep & vaginal swab \\
\hline 2004 & DP733 & sheep & isolate & 2009 & $34 / 23$ & sheep & vaginal swab \\
\hline 2004 & DP735 & cattle & isolate & 2009 & $34 / 25$ & sheep & vaginal swab \\
\hline 2005 & DP698 & sheep & isolate & 2009 & $34 / 51$ & sheep & vaginal swab \\
\hline 2007 & DP819 & cattle & isolate & 2009 & $34 / 53$ & sheep & vaginal swab \\
\hline 2008 & DP750 & cattle & isolate & 2009 & $34 / 54$ & sheep & vaginal swab \\
\hline 2008 & DP756 & goat & isolate & 2011 & 11Q3592 & sheep & vaginal swab \\
\hline 2008 & DP790 & goat & isolate & 2012 & 12Q0778 & sheep & vaginal swab \\
\hline 2008 & DP816 & sheep & isolate & 2013 & 13Q2139 & sheep & vaginal swab \\
\hline
\end{tabular}


Tularaemia and from the National Reference Laboratory of Salmonellosis at the FLI, Jena, from IDEXX in Ludwigsburg, and from the Institute for Medical Microbiology, Jena, respectively (Table 2).

\section{DNA extraction and quantification}

Genomic DNA from inactivated preparations of C. burnetii isolates and from non-Coxiella bacteria was isolated using the High Pure PCR Template Preparation Kit ${ }^{\mathrm{TM}}$ (Roche Diagnostics, Mannheim, Germany) according to the manufacturer's instructions. Quality and purity of the DNA were determined using a Nanodrop ND-1000 spectrophotometer (PEQLAB Biotechnologie GmbH, Erlangen, Germany). DNA quantification was performed with a TaqMan based real-time PCR assay targeting the transposase element IS1111 or the isocitrate dehydrogenase gene (icd) as described by Klee et al. [15] and Hildebrandt et al. [16]. DNA quantification for NineMile RSA493 was performed with the IS1111 real-time PCR assay and genome equivalents (GE) were calculated with 20 IS1111 copies per genome. Priscilla Q177 DNA was quantified with an icd real-time PCR assay and GE calculation was done with one icd copy per genome. Reaction conditions have been described previously [16] with the exception of the master $\operatorname{mix}\left(\right.$ Maxima $^{\text {тм }}$ Probe qPCR
Master Mix, Fermentas, St. Leon-Rot, Germany) and thermocycler (Mx3000P Thermocycler, Agilent Technologies, Santa Clara, CA, USA).

\section{Primer and probe design}

Gene specific primers and probes were designed and optimised using the Array Design software package (Alere Technologies GmbH, Jena, Germany) and the published target sequences from the reference strains NineMile RSA493 (GenBank: AE016828), Henzerling RSA331 and Priscilla Q177. After design, all primers and probes were blasted against the complete GenBank ${ }^{\mathrm{Tm}}$ database (http:// www.ncbi.nlm.nih.gov/BLAST/).

\section{Microarray layout and fabrication}

Oligonucleotides were purchased as 3'-amino-modified oligonucleotides from metabion (Martinsried, Germany) and diluted in Spotting Buffer 1 (Quantifoil Micro Tools, Jena, Germany) to a final concentration of $10 \mu \mathrm{M}$. Arrays were spotted with six-fold redundancy on surfacecoated glass using Alere Technologies spotting machines and assembled into array tubes as described previously $[17,18]$. Internal staining controls (3'-amino and 5'-biotin-modified oligonucleotides) were included for staining control and orientation, as well as negative controls

Table 2 Panel of non-Coxiella strains used for specificity testing

\begin{tabular}{|c|c|c|c|}
\hline Species & Isolate & Species & Isolate \\
\hline Actinobacillus pleuropneumoniae & ATCC 27088 & Haemophilus influenzae & ATCC 9006 \\
\hline Bacillus cereus & ATCC 10876 & Klebsiella pneumoniae & \\
\hline B. megaterium & ATCC 14581 & subsp. pneumoniae & DSM 30104 \\
\hline B. subtilis & ATCC 6633 & Lactobacillus ruminis & DSM 20403 \\
\hline B. thuringiensis & ATCC 10792 & Legionella pneumophila & \\
\hline Bartonella henselae & Marseille & subsp. pneumophila & DSM 7513 \\
\hline B. quintana & $J K-31$ & Mannheimia haemolytica & ATCC 33396 \\
\hline Bordetella bronchiseptica & ATCC 19395 & Oligella urethralis & DSM 7531 \\
\hline Brucella abortus & ATCC 23448 & Pasteurella multocida & DSM 5281 \\
\hline B. melitensis & ATCC 23456 & Proteus mirabilis & DSM 4479 \\
\hline B. suis & ATCC 23444 & Pseudomonas aeruginosa & ATCC 9027 \\
\hline Burkholderia pseudomallei & ATCC 23343 & P. alcaligenes & ATCC 14909 \\
\hline B. cepacia & ATCC 25416 & P. fluorescens & ATCC 13525 \\
\hline B. mallei & ATCC 23344 & P. polymyxa & ATCC 842 \\
\hline Chlamydia psittaci & $\mathrm{C} 1 / 97$ & Rhodococcus equi & DSM 20307 \\
\hline C. abortus & 07 DC0059 & Salmonella typhimurium & 9098 \\
\hline Escherichia coli & DSM 30083 & Staphylococcus aureus & DSM 6732 \\
\hline Francisella tularensis subsp. & & Streptococcus equinus & DSM 20558 \\
\hline tularensis & SchuS4/ FSC 237 & S. parauberis & DSM 6631 \\
\hline \multirow[t]{2}{*}{ F. tularensis subsp. holartica } & LVS/ FSC 155 & Yersinia enterocolitica & \\
\hline & & subsp. palearctica (Y 11) & DSM 13030 \\
\hline
\end{tabular}


(0.1 M Sodium Pyrophosphate (NaPP) Standard pH 9). Probe sequences and array layout are shown in Table 3, and Figure 1, respectively.

\section{PCR amplification of target genes and generation of hybridisation control DNA}

The $20 \mu \mathrm{L}$ PCR reaction mixture contained $1 \times 5$ PRIME HotMasterMix (VWR International GmbH, Darmstadt, Germany), $0.3 \mu \mathrm{M}$ forward primer, and $0.3 \mu \mathrm{M} 5$ '-end biotinylated reverse primer (icd: AT_ICD-F/R, omp/com1: AT_Omp-F/R, IS1111: AT_IS-F/R, cbbE: AT_CbbE-F/R, cbbE: AT_CbhE-F/R, Table 4). Amplifications were performed using a Mastercycler ep (Eppendorf, Germany). The reaction was started with a 1 min denaturation step at $96^{\circ} \mathrm{C}$, followed by 35 cycles with $15 \mathrm{~s}$ of denaturation at $96^{\circ} \mathrm{C}, 20 \mathrm{~s}$ for annealing at $55^{\circ} \mathrm{C}$, and $30 \mathrm{~s}$ for extension at $70^{\circ} \mathrm{C}$. After a final $5 \mathrm{~min}$ extension step at $70^{\circ} \mathrm{C}$ the reaction was stopped and the PCR products submitted to electrophoresis. Hybridisation control DNA was generated from $10^{5} \mathrm{GE}$ of the C. burnetii type strain (NineMile RSA493) using the PCR conditions above and the primer pair HybCtr-F (biotinylated) and HybCtr.

\section{Hybridisation and data analysis}

Hybridisation was carried out at $55^{\circ} \mathrm{C}$ for $60 \mathrm{~min}$ [10]. The hybridisation reaction was monitored using the ATR- $01^{\text {tr }}$ array tube reader (Alere Technologies) at $25^{\circ} \mathrm{C}$ for $10 \mathrm{~min}$, recording one image at the end of incubation time. Signal intensity data with local background correction were obtained using the Iconoclust ${ }^{\mathrm{tax}}$ software, version 3.0 and Pionir/PARTISAN ${ }^{\mathrm{m}}$ arrayLIMS software (Alere Technologies $\mathrm{GmbH}$ ). The normalised intensity

\section{Array layout}

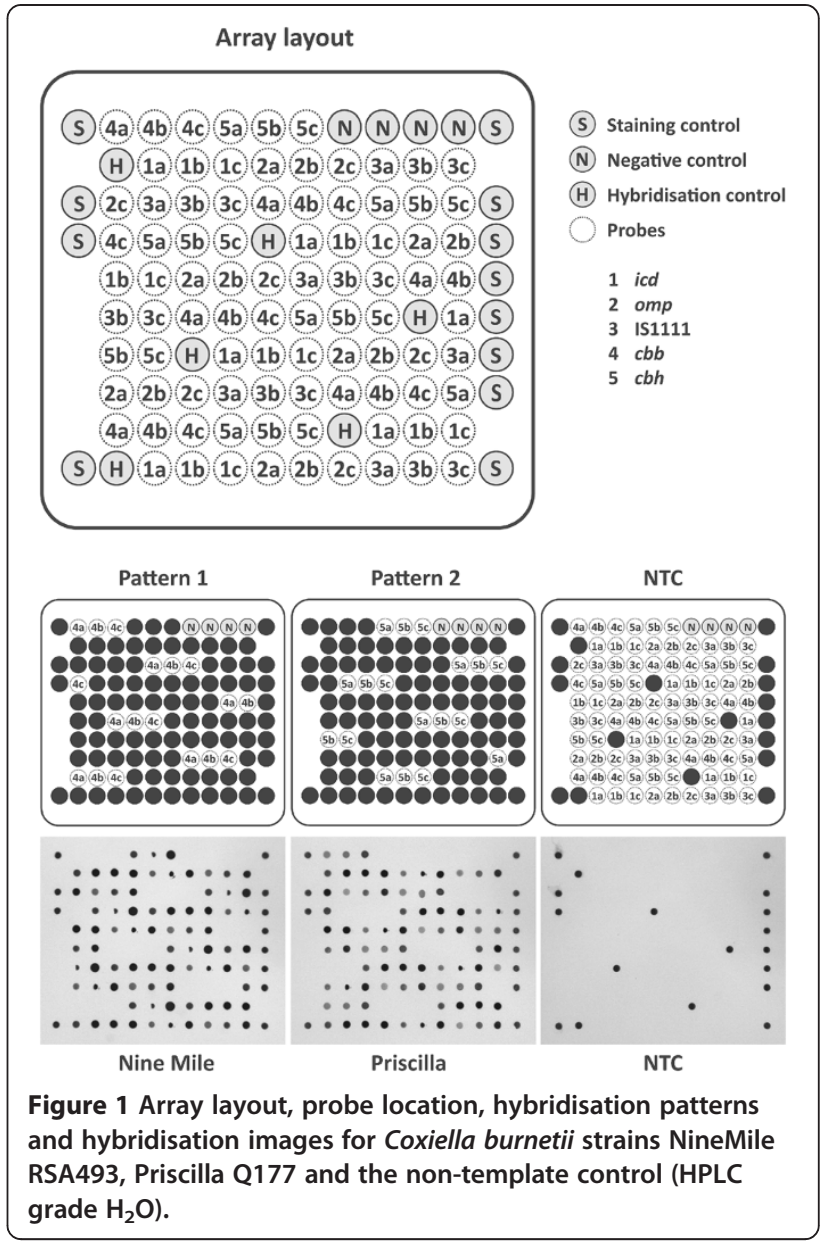

Table 3 Sequences of oligonucleotide probes printed onto the microarray

\begin{tabular}{|c|c|c|c|c|c|}
\hline Probe & Target gene & Sequence $\left(5^{\prime} \rightarrow 3^{\prime}\right)$ & $\operatorname{Tm}\left({ }^{\circ} \mathrm{C}\right)$ & GC (\%) & Length (nt) \\
\hline $1 \mathrm{a}$ & icd & CCTGACCGACCCATTATTCCCTITATCGAAGGAG & 66,1 & 50,0 & 34 \\
\hline $1 b$ & & CCTGACCGACCCATTATTCCCTITATCGAAGG & 65,1 & 50,0 & 32 \\
\hline $1 c$ & & СCCATTATTCCCTTTATCGAAGGAGATGGGATTGG & 64,9 & 46,0 & 35 \\
\hline $2 a$ & omp/com 1 & CGTGGCGATAGCCGCCCCCTCTCAAT & 69,3 & 65,0 & 26 \\
\hline $2 b$ & & CTCCTCAACAAGTCAAAGACATACAAAGCATCG & 63,3 & 42,0 & 33 \\
\hline 2c & & CAAAGCATCGTCCACCATTATTTAGTCAACC & 62,0 & 42,0 & 31 \\
\hline $3 a$ & IS1111 & GTAAAGTGATCTACACGAGACGGGTTAAGCG & 64,0 & 48,0 & 31 \\
\hline $3 b$ & & GCTCAGTATGTATCCACCGTAGCCAGTCTTAAG & 64,6 & 48,0 & 33 \\
\hline $3 c$ & & CTGCGTGGTGATGGAAGCGTGTGGAG & 66,9 & 62,0 & 26 \\
\hline $4 a$ & $c b b E$ & CTAAGAAACTGCTTAAGAGAGGGCAGGGAACG & 65,3 & 50,0 & 32 \\
\hline $4 b$ & & GGGCAGGGAACGATAGTGTGTTGCGGTATTTAC & 67,3 & 52,0 & 33 \\
\hline $4 c$ & & CTTGAAAAACGTAGCGGAAAAGGGACAGTACG & 65,0 & 47,0 & 32 \\
\hline $5 a$ & cbhE & GCTTATTTCGCCCTCGCTGACGGAAGAGGATC & 68,6 & 56,0 & 32 \\
\hline $5 b$ & & CGGAAGAGGATCTITAAGGTCGAATTAGACAGAGATAC & 64,0 & 42,0 & 38 \\
\hline $5 c$ & & GCTGGGGGCCAAGAAAAGTTGCAGACCAG & 68,5 & 57,0 & 30 \\
\hline $\mathrm{H}$ & HybCtr & GACTTACCAACACATCAAAGTTCCCAGC & 61,7 & 46,0 & 28 \\
\hline
\end{tabular}


Table 4 Primers used for amplification of target genes and hybridisation control

\begin{tabular}{|c|c|c|c|c|c|c|}
\hline Name & Target gene & Sequence $\left(5^{\prime} \rightarrow 3^{\prime}\right)$ & PCR product size (bp) & $\operatorname{Tm}\left({ }^{\circ} \mathrm{C}\right)$ & GC (\%) & Length (nt) \\
\hline AT_ICD-F & icd & CGGAGTTAACCGGAGTATCCATC & 178 & 57,6 & 52,0 & 23 \\
\hline AT_ICD-R & & GCATCGACCACGTIITCATG & & 56,2 & 48,0 & 21 \\
\hline AT_Omp-F & omp/com 1 & GCACTATTITTAGCCGGAACC & 144 & 54,9 & 48,0 & 21 \\
\hline AT_Omp-R & & TGCTTCTACTAAAACTTCTGGG & & 53,0 & 41,0 & 22 \\
\hline AT_IS-F & IS11111 & CTGTGTGGAATTGATGAGTGG & 142 & 54,2 & 48,0 & 21 \\
\hline AT_IS-R & & ACGTCCGATACCAATGGTTC & & 55,0 & 50,0 & 20 \\
\hline AT_CbbE-F & $c b b E$ & TAAGGGACATCCACTACCGG & 147 & 55,5 & 55,0 & 20 \\
\hline AT_CbbE-R & & CCCAAATTTAGATCGTCACATTG & & 53,6 & 39,0 & 23 \\
\hline AT_CbhE-F & cbhE & CGATGTCAACTCTAGAGAGC & 147 & 52,5 & 50,0 & 20 \\
\hline AT_CbhE-R & & GCAATCTGCTCGGCAATAAAG & & 55,6 & 48,0 & 21 \\
\hline HybCtr-F & ICD (HybCtr) & CGGAGTTAACCGGAGTATCCATC & 95 & 57,6 & 52,0 & 23 \\
\hline HybCtr-R & & AACTTCTAAAACGGCTTTATTAAC & & 51,5 & 29,0 & 24 \\
\hline
\end{tabular}

(NI) was calculated for each spot using the following equation: $\mathrm{NI}=1-(M / \mathrm{BG})$, with $M$ being the average intensity of the recognised spot and BG the intensity of its local background (Pionir/PARTISAN ${ }^{\mathrm{Tm}}$ software). Values $<0.15$ were considered negative, values $\geq 0.15$ positive.

\section{Determination of assay specificity and detection limit}

In order to assess assay specificity, DNA from a panel of 37 type or in-house reference strains of different bacterial origin was submitted to the above described PCR procedure and subsequent hybridisation (Table 2). The detection limit was the smallest amount of Coxiella DNA detected by the test system for each individual target, and was determined in duplicate using tenfold serial dilutions containing $10^{5}$ to $10^{0}$ genome equivalents (GE) of NineMile RSA493 and Priscilla Q177, respectively.

\section{Results}

\section{PCR amplification of target genes}

Using the reference strains NineMile RSA493 (GenBank: AE016828), Henzerling, and Priscilla Q177, five separate PCR assays where established and optimised for each target (Table 3). All gene targets were successfully amplified and the obtained fragment sizes corresponded to the theoretical values (Table 4) calculated by in silico analysis of the respective target sequences (data not shown).

\section{Oligonucleotide probes and microarray layout}

The selection of the microarray probe panel was based on five well characterised genetic markers of $C$. burnetii. The chromosomal target regions (icd, omp/com1, IS1111) were chosen due to their genetic stability. The plasmid coded target regions $(c b b E, c b h E)$ were selected to identify the Coxiella-specific plasmids QpRS and QpH1 [19,20]. After initial BLAST analysis, all available sequences for the specific targets were used for sequence alignments. The final microarray layout consisted of 16 oligonucleotide probes of 26-38 bp in length with six-fold redundancy (Figure 1).

\section{Hybridisation results}

Initially, hybridisation experiments were done with three reference strains (Nine Mile RSA493, Henzerling RSA331 and Priscilla Q177). Biotin-labelled amplification products of every individual target were pooled and applied to the array. The hybridisation patterns of all three reference strains complied with two patterns; these had been predicted from the in silico analysis of target region sequences derived from the GenBank ${ }^{\mathrm{TM}}$ sequence database: pattern 1 for RSA493 and RSA331, and pattern 2 for Q177, respectively (Figure 1).

In order to validate the new diagnostic assay, German C. burnetii isolates obtained from the German Q-fever network (http://www.fli.bund.de/de/startseite/institute/ institut-fuer-bakterielle-infektionen-und-zoonosen/projekte/bmbf-verbundprojekt-q-fieber.html), and from the German National Reference Laboratory for Q fever were tested; a sample panel of 50 different isolates and 10 clinical samples (vaginal swabs) collected in Germany between 1997 and 2013 from sheep, goats, cattle, fallow deer, ticks, and humans were applied to the array. All analysed isolates revealed hybridisation signals corresponding to pattern 1 .

\section{Determination of detection limits and assay specificity}

The assay detection limit of every target was tested with RSA493 and Q177 in serial dilutions of DNA. Every marker was reliably detected down to DNA amounts of 100 genome equivalents (GE), whereby IS1111 detection was more sensitive with a detection limit of $10 \mathrm{GE}$ (data not shown). The assay specificity was evaluated with 37 type or in-house reference strains of various bacterial 
species (Table 2). No signals were observed in any of the hybridisation experiments with the test panel and internal hybridisation controls, thus confirming 100\% assay specificity.

\section{Discussion}

Diagnosis of Q fever in animal and man usually relies on serological methods, such as indirect immunofluorescence, complement fixation or enzyme-linked immunosorbent assays [5,21]. However, since C. burnetii-specific antibodies only begin to appear several weeks after infection, diagnosis is delayed. DNA based diagnostic assays are therefore more appropriate in terms of speed and specificity, and a plethora of PCR assays suitable for the detection of C. burnetii have been developed [15,22]. Although these assays are usually fast and sensitive and therefore more than adequate for most diagnostic applications, their capacity for multiplexing is limited [8]. This shortcoming has been resolved by using different types of DNA microarrays which have proved to be suitable for a broad range of applications in the microbial research and diagnostics of $\mathrm{Q}$ fever [7,23,24].

The microarray used in the present study was designed to target the chromosomally coded single copy genes isocitrate-dehydrogenase $i c d$, the outer membrane proteincoding gene omp/com 1 and the transpoase gene in the multi copy insertion element IS1111 as well as the plasmid coded markers $c b b E$ on QpRS and $c b h E$ on QpH1. All these markers have been characterised extensively and their suitability as targets for detecting C. burnetii has been confirmed in numerous studies [19,25-29].

The analytical sensitivity of the assay used in the present study was $100 \mathrm{GE}$ for the single copy gene targets icd and omp/com 1 as well as for the plasmid coded targets $c b b E$ and $c b h E$ and $10 \mathrm{GE}$ for the IS1111. Comparable values have been reported by Janse et al. [7], for icd and IS1111 using suspension microarrays and for IS1111 in a multiplex PCR targeting icd, omp/com 1 and IS1111 by de Bruin et al., [29]. The specificity of the array was $100 \%$ with the tested non-Coxiella strains, including the phylogenetic neighbours Legionella spp. and Francisella spp. as well as with Bartonella spp. which have been reported to cross react with Coxiella in serological assays [30]. We did not observe any cross reactions between probes or primers and sample DNA as reported by Janse et al. [7], which could be due to the different oligonucleotide design and different array chemistry.

C. burnetii can harbour four different plasmids of different size and composition, namely QpH1, QpRS, QpDG, QpDV and the chromosomally integrated plasmid-like sequences IPS [25,31,32]. Their role in the biology of C. burnetii is still not clear, but some plasmid genes appear to be essential for conserved functions [33]. Moreover, a potential influence of the different $C$. burnetii plasmids on animal and human disease has been discussed [34]. Early studies suggested that the plasmids QpH1 and QpRS are markers for acute or chronic disease, respectively [32], but this assumption could not be verified in a later study [35]. A small, recent study testing the hypothesis that obstetric complications in $C$. burnetii infections were associated with a particular genotype and the presence of QpDV, found that this plasmid type was detected more frequently in isolates associated with abortions [36]. All samples tested in the present study originated from Germany and harboured the plasmid QpH1. This plasmid type seems to be the predominant type in the isolates circulating in Germany and allegedly the Netherlands [14,36]. Since the present array only includes probes for the plasmids QpH1 and QpRS, which currently appear to be the most frequently occurring plasmid types in C. burnetii [14,35], the existing array could be improved by implementing additional probes for the other known plasmids of $C$. burnetii.

Several arrays have been developed for the detection of C. burnetii [7,23,36,37]. These arrays range from easyto-handle, cheap but inflexible in terms of further probe implementation, to highly sophisticated, expensive-onpurchase but flexible regarding assay design. The Array$\mathrm{Tube}^{\mathrm{TM}}$ platform is an easy-to-handle, middle price range (approx. 15 Euro/Array and PCR), molecular test for high-throughput and parallel analysis of samples. Array designs can be readily expanded by adding further gene targets. Moreover, the modular composition of the platform allows the rapid assembly of custom-made assays, targeting different biological agents, e. g. as part of a Bioweapon-agent-array detecting C. burnetii, Brucella spp., B. mallei/pseudomallei, B. anthracis and Chlamydia spp. [9-12].

\section{Conclusions}

The present array is a rational assembly of established and evaluated targets for the rapid and unequivocal detection of C. burnetii. This array could be applied to the screening of vaginal swabs from small ruminants, screening of environmental samples e.g. on farms, for screening patients with infective endocarditis [38], or of blood donors in regions of high endemicity for $\mathrm{Q}$ fever, e.g. the GermanDutch border area, or in a diagnostic assay screening for atypical pneumonias [23].

\section{Abbreviations}

AT: Array tube; GE: genome equivalent; IS1111: Insertion element 1111; icd: Isocitrate dehydrogenase; omp/com1: Outer membrane protein; NTC: Non-template control; PCR: Polymerase chain reaction; HPLC: High performance liquid chromatography.

\section{Competing interests}

GS and LDS have no financial or other competing interests. RE is an employee of Clondiag/Alere, the producer of the ArrayTube ${ }^{\mathrm{TM}}$ platform. 


\section{Authors' contributions}

RE and GS conceived and designed the experiments. GS analysed the data. LDS drafted and wrote the manuscript. All authors have read and approved the final version of the manuscript.

\section{Acknowledgment}

The authors would like to thank Dr. K. Henning for providing the C. burnetii isolates. Dr. A. Rassbach is thanked for providing the panel of non-Coxiella bacterial strains; Prof. V. Kempf (Frankfurt/M.), Dr. P. Kopp (Ludwigsburg), PD Dr. U. Methner (Jena), PD Dr. J. Rödel (Jena), Dr. K. Sachse (Jena) and PD Dr. H. Tomaso (Jena) are thanked for supplying bacterial DNA. Nadin Lemser is thanked for her excellent technical assistance. Dr. M. J. Sprague is thanked for stylistic improvements of the manuscript. Parts of the present study were presented as a poster at the "National Symposium on Zoonoses Research 2012" in Berlin (October 11-12, 2012). This project was supported by funding from the Federal Ministry for Education and Research (BMBF \#01KI1001A).

\section{Author details}

${ }^{1}$ Friedrich-Loeffler-Institut, Institut für Bakterielle Infektionen und Zoonosen, Naumburger Str. 96a, Jena 07743, Germany. ${ }^{2}$ Alere, Löbstedter Str. 103, Jena 07749, Germany.

Received: 9 December 2013 Accepted: 5 May 2014

Published: 8 May 2014

\section{References}

1. Hanczaruk M, Cutler S, Toman R, Frangoulidis D: Coxiella burnetii. Q Fever. In BSL3 and BSL4 Agents: Epidemiology, Microbiology and Practical Guidelines. 1st edition. Edited by Elschner M, Cutler S, Weidmann M, Butaye P. Weinheim: Wiley-Blackwell; 2012:57-69.

2. Maurin M, Raoult D: Q fever. Clin Microbiol Rev 1999, 12:518-553.

3. Rodolakis A: Q-fever in dairy animals. Ann N Y Acad Sci 2009, 1166:90-93.

4. Oyston PC, Davies C: Q fever: the neglected biothreat agent. J Med Microbiol 2011, 60:9-21.

5. Fournier $P E$, Raoult $D$ : Comparison of $P C R$ and serology assays for early diagnosis of acute Q fever. J Clin Microbiol 2003, 41:5094-5098.

6. Schneeberger PM, Hermans MH, van Hannen EJ, Schellekens JJ, Leenders AC, Wever PC: Real-time PCR with serum samples is indispensable for early diagnosis of acute Q fever. Clin Vaccine Immunol 2010, 17:286-290.

7. Janse I, Bok JM, Hamidjaja RA, Hodemaekers HM, van Rotterdam BJ: Development and comparison of two assay formats for parallel detection of four biothreat pathogens by using suspension microarrays. PLoS One 2012, 7:e31958.

8. McLoughlin KS: Microarrays for pathogen detection and analysis. Brief Funct Genomics 2011, 10:342-353.

9. Schmoock G, Ehricht R, Melzer F, Elschner M, Tomaso H, Neubauer $H$, Al Dahouk S: Development of a diagnostic multiplex polymerase chain reaction microarray assay to detect and differentiate Brucella spp. Diagn Micr Infec Dis 2011, 71:341-353.

10. Schmoock G, Ehricht R, Melzer F, Rassbach A, Scholz HC, Neubauer H, Sachse K, Mota RA, Saqib M, Elschner M: DNA microarray-based detection and identification of Burkholderia mallei, Burkholderia pseudomallei and Burkholderia spp. Mol Cell Probes 2009, 23:178-187.

11. Felder KM, Hoelzle K, Wittenbrink MM, Zeder M, Ehricht R, Hoelzle LE: A DNA microarray facilitates the diagnosis of Bacillus anthracis in environmental samples. Lett Appl Microbiol 2009, 49:324-331.

12. Sachse K, Laroucau K, Hotzel H, Schubert E, Ehricht R, Slickers P: Genotyping of Chlamydophila psittaci using a new DNA microarray assay based on sequence analysis of ompA genes. BMC Microbio/ 2008, 8:63.

13. Sachse $K$, Hotzel $H$, Slickers $P$, Ehricht $R$ : The use of DNA microarray technology for detection and genetic characterisation of chlamydiae. Dev Biol (Basel) 2006, 126:203-210.

14. Hilbert A, Schmoock G, Lenzko H, Moog U, Diller R, Fröhlich A, Hoffmann L, Horner S, Elschner M, Tomaso H, Henning K, Neubauer H, Spraque LD: Prevalence of Coxiella burnetii in clinically healthy German sheep flocks. BMC Res Notes 2012, 5:152.

15. Klee SR, Tyczka J, Ellerbrok H, Franz T, Linke S, Baljer G, Appel B: Highly sensitive real-time PCR for specific detection and quantification of Coxiella burnetii. BMC Microbiol 2006, 6:2.
16. Hildebrandt A, Straube E, Neubauer H, Schmoock G: Coxiella burnetii and coinfections in Ixodes ricinus ticks in Central Germany. Vector Borne Zoonotic Dis 2011, 11:1205-1207.

17. Ehricht R, Adelhelm K, Moneke S, Hulseweh B: Application of Protein Array Tubes to Bacteria, Toxin and Bacteriological Warfare Agent Detection. In Microchip Methods in Diagnostics. Volume 509. Edited by Bilitewski U. New York: Humana Press; 2009:85-105.

18. Monecke S, Ehricht R: Rapid genotyping of methicillin-resistant Staphylococcus aureus (MRSA) isolates using miniaturized oligonucleotide arrays. Clin Microbiol Infect 2005, 11:825-833.

19. Zhang GQ, Hotta A, Mizutani M, Ho T, Yamaguchi T, Fukushi H, Hirai K: Direct identification of Coxiella burnetii plasmids in human sera by nested PCR. J Clin Microbiol 1998, 36:2210-2213.

20. Jäger C, Lautenschlager S, Willems H, Baljer G: Coxiella burnetii plasmid types QpDG and QpH1 are closely related and likely identical. Vet Microbiol 2002, 89:161-166.

21. Rousset $E$, Durand B, Berri M, Dufour P, Prigent $M$, Russo P, Delcroix T, Touratier A, Rodolakis A, Aubert M: Comparative diagnostic potential of three serological tests for abortive $\mathrm{Q}$ fever in goat herds. Vet Microbiol 2007, 124:286-297.

22. Jones RM, Twomey DF, Hannon S, Errington J, Pritchard GC, Sawyer J: Detection of Coxiella burnetii in placenta and abortion samples from British ruminants using real-time PCR. Vet Rec 2010, 167:965-967.

23. Curran T, Coulter WA, Fairley DJ, McManus T, Kidney J, Larkin M, Moore JE, Coyle PV: Development of a novel DNA microarray to detect bacterial pathogens in patients with chronic obstructive pulmonary disease (COPD). J Microbiol Methods 2010, 80:257-261.

24. Leroy Q, Armougom F, Barbry P, Raoult D: Genomotyping of Coxiella burnetii using microarrays reveals a conserved genomotype for hard tick isolates. PLoS One 2011, 6:e25781.

25. Valková D, Kazár J: A new plasmid (QpDV) common to Coxiella burneti isolates associated with acute and chronic Q fever. FEMS Microbiol Lett 1995, 125:275-280

26. Van Nguyen $\mathrm{S}$, To H, Yamaguchi T, Fukushi $\mathrm{H}$, Hirai K: Molecular cloning of an immunogenic and acid-induced isocitrate dehydrogenase gene from Coxiella burnetii. FEMS Microbiol Lett 1999, 175:101-106.

27. Hendrix LR, Mallavia LP, Samuel JE: Cloning and sequencing of Coxiella burnetii outer membrane protein gene com1. Infect Immun 1993, 61:470-477.

28. Howe GB, Loveless BM, Norwood D, Craw P, Waag D, England M, Lowe JR, Courtney BC, Pitt ML, Kulesh DA: Real-time PCR for the early detection and quantification of Coxiella burnetii as an alternative to the murine bioassay. Mol Cell Probes 2009, 23:127-131.

29. de Bruin A, de Groot A, de Heer L, Bok J, Wielinga PR, Hamans M, van Rotterdam BJ, Janse I: Detection of Coxiella burnetii in complex matrices by using multiplex quantitative PCR during a major Q fever outbreak in The Netherlands. Appl Environ Microbiol 2011, 77:6516-6523.

30. La Scola B, Raoult D: Serological cross-reactions between Bartonella quintana, Bartonella henselae, and Coxiella burnetii. J Clin Microbiol 1996, 34:2270-2274

31. Stoenner HG, Lackman DB: The biologic properties of Coxiella burnetii isolated from rodents collected in Utah. Am J Hyg 1960, 71:45-51.

32. Samuel JE, Frazier ME, Mallavia LP: Correlation of plasmid type and disease caused by Coxiella burnetii. Infect Immun 1985, 49:775-779.

33. Maturana P, Graham JG, Sharma UM, Voth DE: Refining the plasmid-encoded type IV secretion system substrate repertoire of Coxiella burnetii. J Bacteriol 2013, 195:3269-3276.

34. Russell-Lodrigue KE, Andoh M, Poels MW, Shive HR, Weeks BR, Zhang GQ, Tersteeg C, Masegi T, Hotta A, Yamaguchi T, Fukushi H, Hirai K, McMurray DN, Samuel JE: Coxiella burnetii isolates cause genogroup-specific virulence in mouse and guinea pig models of acute $Q$ fever. Infect Immun 2009, 77:5640-5650.

35. Glazunova O, Roux V, Freylikman O, Sekeyova Z, Fournous G, Tyczka J, Tokarevich N, Kovacava E, Marrie TJ, Raoult D: Coxiella burnetii genotyping. Emerg Infect Dis 2005, 11:1211-1217.

36. Angelakis E, Million M, D'Amato F, Rouli L, Richet H, Stein A, Rolain JM, Raoult D: Q fever and pregnancy: disease, prevention, and isolate specificity. Eur J Clin Microbiol Infect Dis 2013, 32:361-368.

37. Frangoulidis D, Rodolakis A, Heiser V, Landt O, Splettstoesser W, Meyer $\mathrm{H}$ DNA microarray-chip based diagnosis of Q- fever (Coxiella burnetii). Clin Microbiol Infect 2009, 15(Suppl 2):165-166 
38. Habib G, Hoen B, Tornos P, Thuny F, Prendergast B, Vilacosta I, Moreillon P, de Jesus Antunes M, Thilen U, Lekakis J, Lengyel M, Müller L, Naber CK, Nihoyannopoulos P, Moritz A, Zamorano JL: ESC Committee for Practice Guidelines on the Prevention, Diagnosis, and Treatment of Infective Endocarditis (new version 2009): the Task Force on the Prevention, Diagnosis, and Treatment of Infective Endocarditis of the European Society of Cardiology (ESC). Endorsed by the European Society of Clinical Microbiology and Infectious Diseases (ESCMID) and the International Society of Chemotherapy (ISC) for Infection and Cancer. Eur Heart J 2009, 30:2369-2413.

doi:10.1186/1751-0147-56-27

Cite this article as: Schmoock et al.: DNA microarray-based detection of Coxiella burnetii, the causative agent of $\mathrm{Q}$ fever. Acta Veterinaria Scandinavica 2014 56:27.

\section{Submit your next manuscript to BioMed Central and take full advantage of:}

- Convenient online submission

- Thorough peer review

- No space constraints or color figure charges

- Immediate publication on acceptance

- Inclusion in PubMed, CAS, Scopus and Google Scholar

- Research which is freely available for redistribution 